Uludag Univ. J. Fac. Vet. Med.

32 (2013), 2: 57-61

\title{
Bir Lori Irkı Papağanda (Lorius garrulus) Rastlanan Lipom Olgusu
}

\author{
Mustafa Barış AKGÜL ${ }^{1} \quad$ İsmail Altuğ ŞEN ${ }^{1} \quad$ Volkan İPEK $^{2}$ \\ Aylin ALASONYALILAR DEMIRER ${ }^{2} \quad$ Melike ÇETİN $^{1} \quad$ Deniz SEYREK İNTAŞ $^{1}$
}

Geliş Tarihi: 11.02 .2014

Kabul Tarihi: 04.04.2014

Özet: Bu olgu sunumunda 21 yaşlı, erkek, lori ırkı (lorius garrulus) bir papağanda belirlenen tümöral oluşumun tanısı ve sağaltımından bahsedilmektedir.

Hasta kliniğimize bir aydır boyun bölgesinde şişkinlik geliştiği şikayeti ile getirdi. Klinik muayenede boynun sağ tarafında ceviz büyüklüğünde, üzerindeki tüyler dökülmüss, katı-esnek kıvamda, sınırları belirgin bir yapı saptandı. Genel anestezi altında kitle ekstirpasyonu gerçekleştirildi. Örneğin histopatolojik değerlendirmesi sonucunda lipom olduğu belirlendi.

Anahtar Kelimeler: Lipom, Papağan, Tümör.

\section{A case of Lipoma in a parrot (Lorius garrulus)}

\begin{abstract}
This is a case report about the diagnosis and operative treatment of a lipoma in a 21 -years-old male parrot (Lorius garrulus).

The patient was presented with a growing mass in the cervical region since one month. Clinical examination showed a well-defined soft tissue mass on the right lateral aspect of the neck. The feathers on the surface were lacking and the consistency was firm-elastic. The mass was removed under general anaesthesia. Histopathological investigation revealed a lipoma.
\end{abstract}

Key Words: Lipoma, parrot, tumour.

\section{Giriş}

Tümörler evcil kuşlarda, bilhassa papağangillerde, bunlardan da muhabbet kuşlarında çok yaygındır ve daha çok deri ve urogenital sistemde sık rastlanır. Vahşi kuşlarda, evcillere oranla daha az rastlandığı bildirilmiştir. Karşılaştırma yapıldığında evcil kuşların daha uzun ömürlü olmaları ve iyi beslenmeleri, kanserojenlere daha fazla maruz kalmaları ve irk özelliklerinin bu tür oluşumlara yatkın olması buna sebep gösterilmiştir 6 .

Lipom, yağ hücreleri ve lipoblastların iyi huylu ve en sık görülen tümörüdür. Çalışmalar- da muhabbet kuşlarında \%10-40 oranında, amazon papağanı ve rose-breed kakadularda da bu orandan biraz daha az olmakla birlikte sıcça görüldüğü bildirilmiştir ${ }^{1-3,14}$. Obez, yüksek enerjili diyetler ile beslenen, yetişkin ve yaşlı kuşlarda oluşma olasılığ daha fazladır ${ }^{4,18}$. Herhangi bir cinsiyet ayrımı bildirilmemiştir. Lipomlar ince bir kapsula ile sınırlı, multilobüler tarzda, soluk sarı renkte kitleler olup, palpasyonda deri altı bağ dokuda serbest hareket eden yapıdadır. Üzerinde bulunan deri genellikle normal olsa da, bazen nekrotik ve yangilı olabilir6 .

Memeli hayvanlarda karşılaşılan palpe edilebilir kitlelerde klinik muayenenin yanı sıra

$1 \quad$ Uludağ Üniversitesi Veteriner Fakültesi Cerrahi Anabilim Dalı. mbagul@uludag.edu.tr

2 Uludağ Üniversitesi Veteriner Fakültesi Patoloji Anabilim Dalı 
ultrasonografi ile kitlenin boyutu, şekli, iç yapıs1, sınırları ve yaygınlığı, akustik iletim ve vasküler beslenme özellikleri belirlenerek kitlenin tiplendirilmesi ve derecelendirilmesi yap1lır ve ona göre sağaltım ve prognoz belirlenir ${ }^{12}$.

Lipomlar lipogranuloma, yabancı cisme bağl1 yangilar, apseler, fitıklar ya da diğer deri tümörleri ile histopatolojik inceleme yapılarak ayrımlanmalıdır 6 .

Kuşlarda lipomlar ülserleşerek nekroze olur ve kanamaya neden olabilirler. Diyet düzenleme ile operasyon öncesinde adipöz doku oranı azaltılabilir ve kanama eğilimi düşürülerek operasyon kolaylaştırılabilirr ${ }^{6,19,21}$.

\section{Olgu Tanımı}

Lori 1rkı (Lorius garrulus), 21 yaşlı, erkek bir papağan, boyun bölgesinde yaklaşık bir ay önce farkedilen ve son 15 gündür büyüdüğü saptanan bir şişkinlik şikayeti ile U.Ü. Veteriner Fakültesi Hayvan Hastanesi Cerrahi Kliniğine getirildi. Kuşta daha önce herhangi bir hastalık ya da tümöral bir oluşum görülmemiş. Hastanın papağan yemi ile beslendiği, başka herhangi bir besin verilmediği ve kitlenin kuşun beslenmesinde bir engel oluşturmadığı söylendi.

Hastanın genel muayene bulguları normaldi. Özel muayene bulgularında boyun bölgesinin sağ tarafinda, yaklaşık 1,5-2 cm çapında, üzerindeki tüylerin yer yer dökülmüş ve dikleşmiş olduğu, şişkinliğin üzerindeki deri kısmının düzgün ve renginin normal olduğu bir yapı görüldü. Palpasyonda kitlenin ne deri, ne de altındaki dokularla bağlantılı olmadığı, derialtı bağdokusu içerisinde sınırlı hareket ettiği, kıvamının yumuşak ile katı esnek arasında olduğu saptandı. Vücut üzerinde başka bir patoloji saptanmadı. Hastanın alınan ventro-dorsal ve latero-lateral radyografilerinde boyun bölgesinin sağ tarafinda homojen, yağ opasitesinde, eliptik şekilli bir yapı saptandı (Resim 1). Ultrasonografik muayenesinde 7,5 $\mathrm{MHz}$ frekansinda lineer bir prob kullanıldı. Deri altı bağ dokusunda eliptik şekilli, sınırları belirgin, yaklaşık $1,7 \mathrm{x}$ $1,4 \mathrm{~cm}$ ebatlarında bir yapı saptand. Kitlenin ekojenitesi homojen olarak dağılmış, yaygın, hiperekoik noktacıklardan ve çizgiciklerden ibaretti (Resim 2). Bu bulgulara istinaden boyun bölgesinde lipom şüpheli tanısı kondu ve ayırıcı tanı olarak diğer tip neoplaziler ve düşük olasılikla kronik apse, granulom veya eski hematom düşünüldü. Kitlenin total ekstirpasyonuna karar verildi.

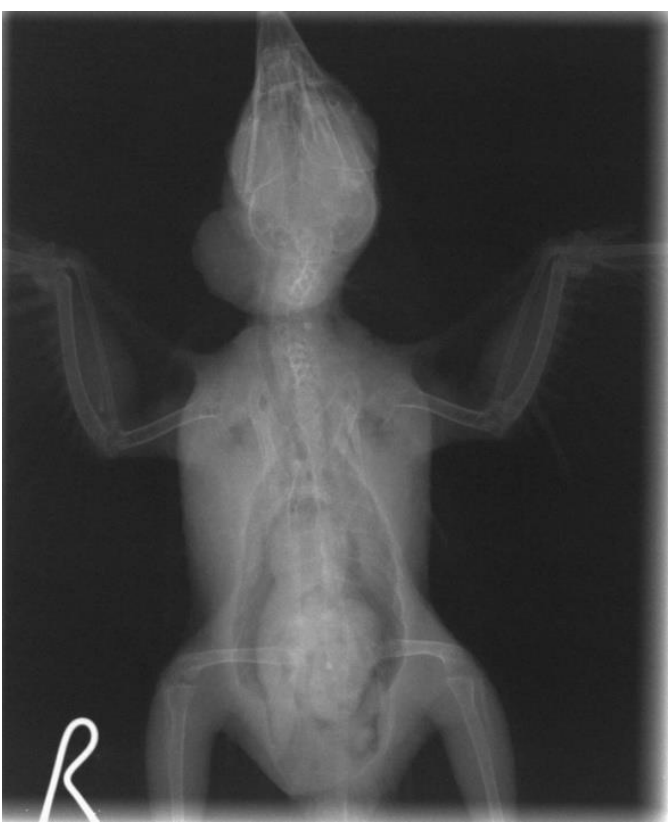

\section{Resim 1:}

Ventro-dorsal radyografide boynun să̆ında yaklaşık 1,5-2cm büyüklügünde, homojen bir sişkinlik görülmektedir. Bu kitlenin opasitesinin yumuşak doku opasitesinden biraz daha radyolusent olduğu dikkati çekmiştir.

Figure 1:

On the ventro-dorsal projection there is a homogenous, round shaped mass on the right lateral aspect of the neck. The opacity appears mildly less opaque compared to soft tissues.

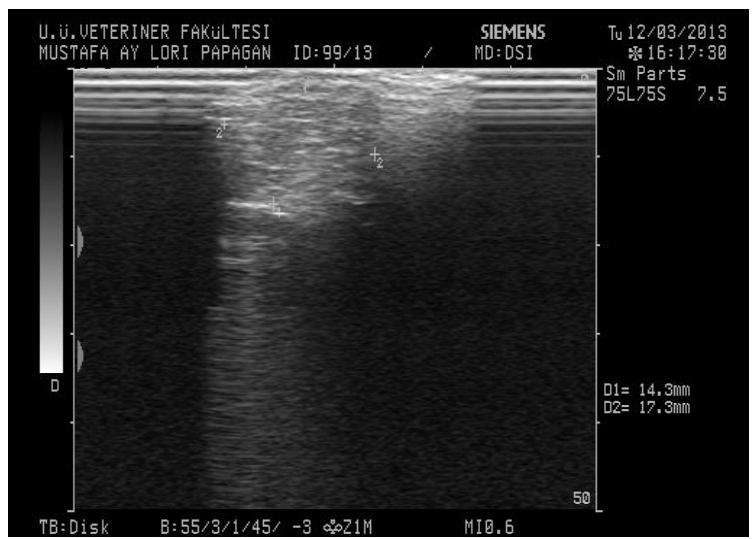

Resim 2:

Lipomun ultrasonografik görüntüsü. Kitlenin sinırlarının belirgin ve solid olduğu, ekojenitesinin homojen olduğu ve içerisinde muntazam dağılmış, paralel, hiperekoik çizgicik ve noktacıkların bulunduğu belirlenmistir.

Figure 2:

Ultrasound image of the lipoma. The mass is clearly defined and solid, its echogenicity is homogenous and contains evenly distributed parallel hyperechogenic dots and stripes. 
Hasta operatif girișime hazırlandı. Anestezi için hastaya yüz maskesi ile $\% 2$ isoflurane 1 1/dk oksijen uygulandı. Operasyon bölgesindeki tüyler uzaklaştırıldı. Dilüe antiseptik solüsyonu ile bölgenin temizliği yapıldı. Ardından iyotlu solüsyon bölgeye uygulanarak operasyon sahasının antisepsisi sağlandı (Resim 3). Şişkinlik üzerinden kavun dilimi ensizyonu yapıldı, ardından küt ve keskin diseksiyonlarla kitle çevresindeki ve altındaki dokudan serbestleştirilerek uzaklaştırıldı (Resim 4). Ensizyon hattı monofilament, emilmeyen 4/0 numara dikiş materyali $\left(\right.$ Ethicon $\left.^{\circledR}\right)$ ile basit ayrı dikişler ile kapatıldı. Hasta anesteziden komplikasyonsuz olarak uyandi. Post operatif analjezi için karprofen (Rimadyl flk, Pfizer ${ }^{\circledR}$ ) 2mg/kg dozunda tek doz i.m. olarak uyguland1. Antibiyoterapi doksisilin (Tetradox kapsül, Fako ${ }^{\circledR}$ ) $20 \mathrm{mg} / \mathrm{kg}$ p.o. 7 gün uygulanması ve yara hattına \%10 Povidon iodin (Poviodeks, KİM-PA ${ }^{\circledR}$ ) tuşe edilmesi önerildi. Hasta sahibi kontrollere gelmediği için post operatif dönemde hasta takibi yapılamadı.

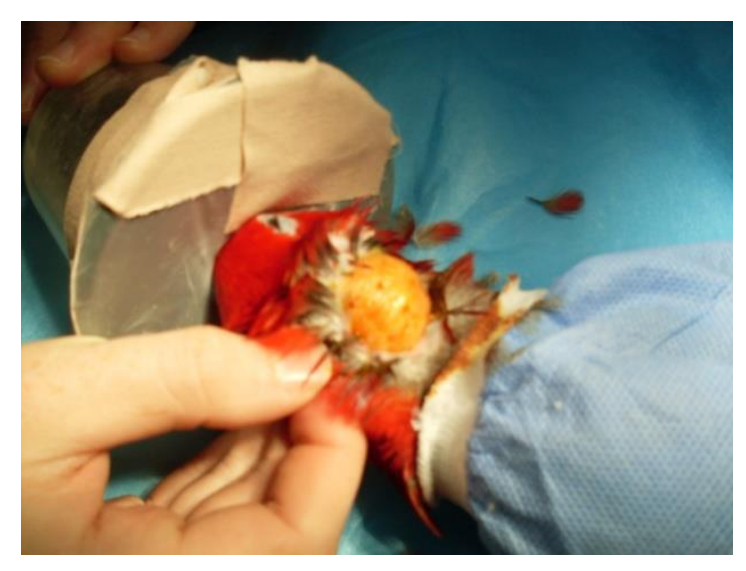

Resim 3:

Preoperatif hazırlık aşamasında kitlenin görünümü.

Figure 3:

Appearance of the mass during the preoperative period.

Alınan yapının histopatolojik incelenmesinde taze dokundurma preparatından hazırlanan sitolojide poligonal şekilli hücrelerin, oval bir çekirdek ile birlikte, sitoplazmalarında keskin kenarl1, yuvarlak vakuollere sahip olduğu görüldü. Sudan B siyah boyası ile sitoplazmadaki lipid damlalarının mavimsi siyah renkte boyanmas1 ile lipidlerin varlığı konfirme edildi. Histopatolojide dış sınırı ince, fibröz bir kapsülle çevrili kitlenin olgun, iyi diferensiye adiposit hücrelerden oluştuğu ve birkaç sahada fibröz septumlar aracılığıyla lobüllere ayrıldığı görüldü. Kitle genelindeki adipositler ince bir hücre membranına, yassı, kenara itilmiş bir çekirdeğe ve geniş, boyanmayan bir sitoplazmaya sahipti. Sitolojik ve histopatolojik boyamalar sonucunda kitlenin lipom tanısı doğruland.

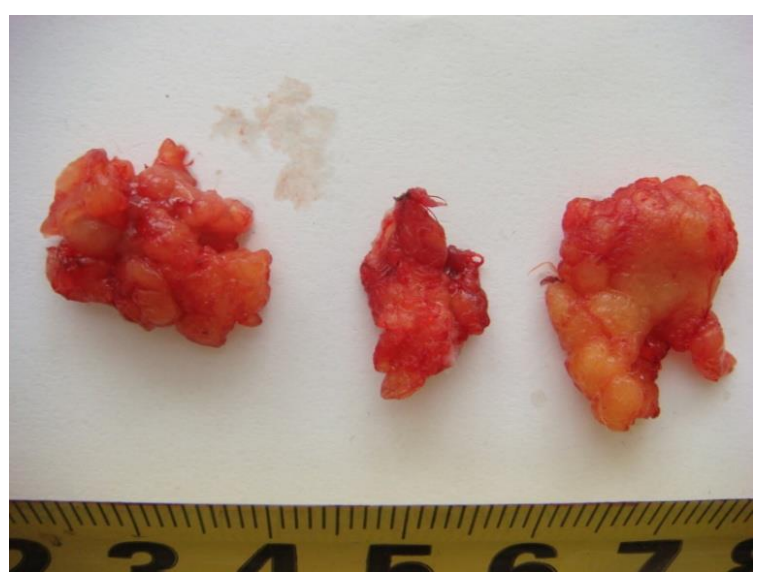

Resim 4:

Uzaklaştırılan kitlenin makroskopik, lobüler görünümü.

Figure 4:

Macroscopical lobular appearance of the mass after removal.

\section{Tartışma}

Tümöral yapıların evcil kuşlarda, bilhassa papağangillerde çok yaygın olduğu ifade edilmektedir ${ }^{6}$. Lipomun adipöz, yüksek enerjili diyetler ile beslenen, yetişkin ve yaşlı kuşlarda oluşma olasıllığının daha fazla olduğu bildirilmektedir ${ }^{3,15}$. Lipom genellikle tek, ancak bazen birden fazla olarak vücudun herhangi bir yerinde oluşabilir. Bunlar en çok sternum, kanat, bacak ve karın bölgesinin cilt altı dokularında bulunur ${ }^{6,8,9,11}$. Daha az olarak da coelomic boşlukta yer alırlar. Lipomlar aylar, yıllar içinde yavaş yavaş gelişebileceği gibi, bir anda hızlı bir şekilde de büyüyebilirler. Bu olgu sunumundaki papağanın ileri yaşta olması, kafeste ve ev ortamında yaşaması, lipom oluşumu için hazırlayıcı bir faktör oluşturmuştur. Literatürlerde belirtiği gibi boyun bölgesinde ve hılı bir biçimde oluşmuştur.

Eski lipom olgularında kitlenin büyümesiyle birlikte deri yüzeyinde ülseratif alanların oluşabileceği bildirilmektedir ${ }^{7}$. Bu olguda deri bütünlügünün bozulmadığ 1 gözlenmiştir. Ayrıca kalça ve ekstremitelerde oluşan büyük kitlelerde tutunma, tırmanma ve uçma gibi fonksiyonların yapılamamasina neden olurlar ${ }^{18}$. Olgumuzda 
kitlenin boyun bölgesinde lokalize olmasıyla herhangi bir fonksiyon kaybı oluşturmamıştır.

Küçük hayvanlarda lipomların ultrasonografik görünümleri detaylı olarak tarif edilmektedir ${ }^{10,12,20}$ ancak kuşlarda görülen lipomların ultrasonografik görünümü hakkında bir çalışmaya rastlanmamıştır. Bir çalışmada ultrasonografik değerlendirmesi yapılan 24 köpekteki 55 lipomun 26'sının görünümü etrafındaki yumuşak dokulara göre izoekoik, 19'unun hipoekoik ve 10'unun hiperekoik olduğu saptanmıştır. Bütün hastalarda hiperekoik bir kapsulaya rastlandığ bildirilmiştir ${ }^{20}$.

İntraabdominal lipom saptanan bir köpekte, ultrasonografik olarak dış sınırlarının belli belirsiz ve hiperekoik görünümde olduğu, iç yüzeyinin düzensiz yapıda ve amorf, hiperekoik dokuların lümene doğru çıkıntı oluşturduğu, merkezinin ise anekoik yapıda olduğu gözlenmiştir. $\mathrm{Bu}$ anekoik alanın hiperekoik noktasal yapılarla dolu olduğu ve bu yapıların herhangi gölge ya da reverberasyon artefaktı oluşturmadığ1 gözlenmiştir. Bunun gibi sıvı içeriği de bulunan lipomlar nekrotik lipom olarak tanımlanir ${ }^{5}$.

Başka bir çalışmada ultrasonografik değerlendirmesi yapılan 86 köpeğin 23'ünde lipom saptanmıştır. Bu 23 hastada lipomlar homojen yapıda, izoekoik görünümde olduğu ve iç dokularının artefakt oluşturmadığı görülmüştür. 22 'sinde belirgin kenarlı ve 20'sinde düzgün bir dış yapısı olduğu görülmüştür ${ }^{12}$. Bu olguda da ince, hiperekoik bir kapsula gözlenmiş ve solid dokunun içerisinde diğer küçük hayvan türlerinde de karşılaștığımız tipik, hiperekoik noktacık ve çizgicikler saptanmış, artefakt görülmemiştir.

Hayvanlarda karşıllaşılan neoplastik oluşumların tanısı genel olarak klinik görünüm, görüntüleme bulguları ve ince iğne aspirasyonu ve/veya biyopsi sonuçları ile konur. Burada tümörün tipinin sadece sitolojik/histopatolojik olarak belirlenebileceği vurgulanmaktadır ${ }^{10,17}$. Buna karşın lipomlar, tipik görünümleri nedeniyle, tanısı ultrasonografik olarak konabilen tek tümör tipi olmakla birlikte, invaziv olan ve olmayan lipomların ultrasonografi yöntemiyle birbirinden kesin olarak ayırt edilmesinin mümkün olmadığ bildirilmektedir $^{12,10}$. Sitolojik muayenede liposarkom ya da miyelolipom'un ayrımı tam olarak yapılamayacağı için kitleden biyopsi alınarak incelenmesi, tanının kesinlik kazanması için önemlidir ${ }^{15}$. Bu nedenle olgumuzda radyolojik ve ultrasonografik bulgulara dayanarak lipom olduğu düşünülen kitlenin total ekstirpasyonuna karar verilmiştir.

Lipom ile karşılaşılan hastalarda diyetlerdeki yağ oranlarının azaltılması, hareketin artt1rilması, L-carnitine ve L-thyroxine kullanılmas1 önerilmektedir ${ }^{9}, 13,16,19$. Ayrıca anormal tiroid (hipotiroidizm) fonksiyonlarından ileri gelen durumlarda iyot içeren preparatlardan faydalanılabilmektedir ${ }^{8}$. Lipom saptanan çok sayıda kuşta bunun karaciğer hastalıklarından kaynaklı olduğu bildirilmiştir ${ }^{18}$. Bunların yanında kemoterapi, radyoterapi ve immunoterapi gibi uygulamalar da yapılmaktadır ${ }^{13}$. Kuş tümörlerinin tedavisinde en çok gerçekleştirilen uygulamalar tümörlü dokunun cerrahi eksizyonudur. Eksizyon esnasında hastanın ölümüne yol açacak şiddetli kanamalara karşı küt diseksiyonlarla çalışılmasına dikkat çekilmektedir. Olgumuzda tüm operasyon süresince ve erken post op dönemde herhangi bir komplikasyon şekillenmemiştir.

\section{Sonuç}

Sağlıklı lorilerde lipom gibi yüzeysel kitlelerin görüntülü tan1 yöntemleri ile yüksek doğruluk oranıyla tanısının konması ve bunların inhalasyon anestezisi altında kolayca operatif olarak uzaklaştırılması başarı ile mümkün olabilmektedir. Burada kuştaki lipomun ultrasonografik görünümünün küçük hayvanlardaki lipomun görünümüne çok benzediği, ancak kuşlardaki lipomların genel görüntü özelliklerinin belirlenmesi için çok sayıda kuşun incelendiği ileri çalışmalara ihtiyaç olduğu vurgulanabilir.

\section{Kaynaklar}

1. Baker JR: A survey of causes of mortality in budgerigars. (Melopsittacus undulatus). Vet Rec, 106: 10-12, 1980.

2. Beach JE: Disease of budgerigars and other cage birds. A survey of post-mortem findings. J Small Anim Pract, 74: 10-15, 63-68, 134-140, 1962.

3. Blackmore DK: The clinical approach to tumours in cage birds - I. The pathology and incidence of neoplasia in cage birds. J Small Anim Pract, 7: 217-223, 1966.

4. Burgmann PM: Common psittacine dermatologic diseases. Semin Avian Exotic Pet Med, 4: 169183, 1995.

5. Clapp K, Rademacher N, Gaschen L. Imaging diagnosis-intra-abdominal lipoma. Vet Radiol Ultrasound. 2009;50(6):644-5.

6. Filippich L: Tumor control in birds, Seminars in Avian and Exotic Pet Medicine, 25-30, 2004. 
7. Gill JH: Avian skin diseases. Vet Clin North Am Exotic Anim Pract 4: 463-492, 2001.

8. Hillyer EV, Quesenberry KE, Baer K: Basic avian dermatology. Proc Assoc Avian Vet, Seattle, Washington, 101-121, 1989.

9. Koski MA: Dermatologic diseases in psittacinebirds: An investigational approach. Semin Avian Exotic Pet Med, 11 (3): 105-124, 2002.

10. Kramer M, D'Anjou MA, Muskuloskeletal Sistem. Küçük Hayvan Ultrasonografi Atlası, Ed. Penninck D, D'Anjou MA, Medipress, 2013.

11. McCluggage DM: Survey of the integument: Selected topics. Semin Avian Exotic Pet Med, 2 (2): 76- 82, 1993.

12. Nyman HT, Kristensen AT, Lee MH, Martinussen T, McEvoy FJ. Characterization of canine superficial tumors using gray-scale B mode, color flow mapping, and spectral doppler ultrasonography--a multivariate study. Vet Radiol Ultrasound. 2006; 47(2): 192-8.

13. Özsoy S, Aydınoğlu G, Erdoğan Ö: Kliniğimize Getirilen Muhabbet Kuşu ve Papağanlarda (Toplam 28 Olgu) Rastladığımız Tümörlerin Değerlendirilmesi. Veteriner Cerrahi Dergisi, 14 (2): 12-18, 2008.

14. Petrak Ml, Gilmore CE: Neoplasms. Diseases of Cage and Aviary Birds. Petrak, M.L. (ed): $2^{\text {nd }}$ ed., Philadelphia, Lea \& Febiger, 606-637, 1982.
15. Reavill DR, Schmidt R: Avian surgical pathology, Laboratory Medicine: Avian and Exotic Pets, Philadelphia, PA, Saunders, 133-146, 2000.

16. Rosskopf WJ, Woerpel RW: Remission of lipomatous growths in a hypothyroid budgerigar in response to L-thyroxine therapy, Vet Med/Small Anim Clin, 78: 1415-1418, 1983.

17. Rübel A, Isenbügel E: Papageien. Krankheiten der Heimtiere, Ed. Gabrisch K, Zwart P, Schlütersche Verlag, 145-194, 1987.

18. Turrel JM, McMillan MC, Paul-Murphy J: Diagnosis and treatment of tumors of companion birds I, AAV Today, 1 (3): 109-116. 1987.

19. Voe, DS, Trogdon M, Flammer K: Preliminary Assessment of the Effect of Diet and L-Carnitine Supplementation on Lipoma Size and Bodyweight in Budgerigars (Melopsittacus undulatus), Journal of Avian Medicine and Surgery, 18 (1): 12-18. 2004.

20. Volta A,, Bonazzi M, Gnudi G, Gazzola M, Bertoni G: Ultrasonographic Features of Canine Lipomas, Veterinary Radiology \& Ultrasound, 47 (6): 589-591, 2006.

21. Wilson H, Rawlings C, Latimer K, Strunk A, Hanley C, Lester VK: Comparison ultrasonic surgical aspirator and $\mathrm{CO}_{2}$ laser for lipoma resection in budgerigars (Melopsittacus Undulatus). Journal of Avian Medicine and Surgery, 18 (2): 95-100, 2004 
